\title{
Replacing sugar with $S$. rebaudiana extracts on the physicochemical and sensory properties of strawberry ice cream
}

\author{
Substituição do açúcar com extratos de $S$. rebaudiana sobre as \\ propriedades físico-químicas e sensoriais de sorvete de morango
}

\author{
Irma Aranda-Gonzalez ${ }^{\mathrm{I}}$ Maribel Perera-Pacheco ${ }^{\mathrm{I}}$ \\ Enrique Barbosa-Martín ${ }^{\mathrm{I}}$ David Betancur-Ancona ${ }^{\mathrm{I*}}$
}

\section{ABSTRACT}

Ice cream is a product whose formulation requires considerable amounts of sugar. In addition to providing flavor, sugar contributes to the physicochemical characteristics of ice cream but its consumption in large quantities is related to chronic diseases such as diabetes and obesity. For this reason, the food industry seeks to formulate products with sweeteners that preserve the physicochemical and sensory characteristics of the original product. Stevia rebaudiana is a plant that naturally contains glycosides with no calories and high sweetening capacity and it is considered safe for consumption. Therefore the aim of this research was to evaluate the effect of replacing sugar with different levels of extracts of S. rebaudiana Morita II and Criolla, on the physicochemical and sensory properties of strawberry ice cream. Using a $2 \times 2$ factorial experimental design, a total of 4 formulations were prepared with two levels of concentration of the aqueous extract of Stevia rebaudiana (5 or 8\%) and the variety of $\boldsymbol{S}$. rebaudiana (Morita II or Criolla). Proximate composition, physicochemical properties and sensory evaluation were determined in processed products. The proximate analysis of strawberry ice cream varied significantly $(P<0.05)$ depending of variety and level used on the formulation. The viscosities of all ice cream mixes were decreasing as the shear rate was increased, indicating a pseudoplastic behavior. The sensory analysis showed differences $(P<0.05)$ among the formulations tested, however the score of all products were above the indifference point, suggesting that all of these formulations may have a commercial potential.

Key words: Stevia rebaudiana, ice cream, sweetener, proximate analysis, sensory evaluation.

\section{RESUMO}

Sorvete é um produto cuja formulação requer quantidades consideráveis de açúcar. Além de proporcionar o sabor, o açúcar contribui para as propriedades físico-químicas do sorvete, mas o seu consumo em grandes quantidades está relacionada com as doenças crônicas, como diabetes e obesidade. Por essa razão, a indústria alimentícia buscou formular produtos com adoçantes para manter as propriedades fisicoquímicas e sensoriais do produto original. Stevia rebaudiana é uma planta que contém naturalmente glicosídeos sem calorias com alta capacidade adoçante, cujo consumo é considerado seguro. Portanto, o objetivo deste estudo foi avaliar o efeito da substituição do açúcar por diferentes níveis de extratos de $\boldsymbol{S}$. rebaudiana Morita II e Criolla, sobre as propriedades fisicoquímicas e sensoriais do sorvete de morango. Usando um modelo experimental de fator $2 \times 2$, um total de 4 formulações foram preparadas com 2 níveis de concentração de extrato aquoso de Stevia rebaudiana (5 ou 8\%) e a variedade de Stevia (Morita II ou Criolla). Os produtos processados foram submetidos a análises proximais e físico-químicas, e avaliação sensorial foi realizada para três deles. A análise do sorvete de morango teve uma variação estatisticamente significativa $(P<0,05)$, dependendo da variedade e do nivel utilizado na formulação. A viscosidade da mistura de sorvete diminuía com o aumento da velocidade de corte, indicando um comportamento pseudoplástico. A análise sensorial mostrou que não houve diferenças significativas $(P>0,05)$ entre as formulações avaliadas e a pontuação de todos os produtos estava acima do ponto de indiferença, indicando que todos eles podem ter um potencial comercial.

Palavras-chave: Stevia rebaudiana, sorvete, adoçante, análise proximal de avaliação sensorial.

\section{INTRODUCTION}

"Ice cream is a food produced by freezing, while stirring, a pasteurized mix consisted of one or more of the optional dairy ingredients, and may contain

\footnotetext{
'Facultad de Ingeniería Química, Universidad Autónoma de Yucatán (UADY), Periférico Norte Kilometro, km 33.5, Chuburna de Hidalgo Inn, 97203, Mérida, YUC, México. E-mail: bancona@uady.mx. "Corresponding author.
} 
one or more of the optional caseinates, subjected to the conditions herein after stablished, one or more of the optional hydrolyzed milk proteins, subjected to the conditions herein after the stablished, and other safe and suitable nonmilk-derived ingredients; and excluding other food fats, except those natural components of flavoring ingredients used or added in incidental amounts to accomplish specific functions. Ice cream is sweetened with safe and suitable sweeteners and may be characterized by the addition of flavoring ingredients" (FDA 2015). In the ice cream formulation, the main sweetener used is sucrose although other sugars can be used, such as glucose, fructose and sugar alcohols (CAILLET et al., 2003).

Higher intake of added sugars is associated with higher energy intake and lower diet quality, which can increase the risk for obesity, pre-diabetes, type-2 diabetes, and cardiovascular disease (KLURFELD, 2012). Therefore, the food industry has used alternatives to reduce the sugar content in their products, such as natural and artificial sweeteners (ACADEMY OF NUTRITION AND DIETETICS, 2012).

Stevia rebaudiana Bertoni is a good alternative, due to its high content of steviol glycosides which are natural, non-caloric and with a high sweetener capacity (200-300 times more than sugar) and are considered generally safe (GRASS) by the Food and Drug Administration (ACADEMY OF NUTRITION AND DIETETICS, 2012). Among the varieties of $\boldsymbol{S}$. rebaudiana, Criolla and Morita II are the most used in the world. Criolla variety can be reproduced by cross-pollination (RAMÍREZJARAMILLO et al., 2011) allowing the producers to make empirical selections depending on weather conditions (LEMUS-MONDACA et al., 2012). Morita II variety was generated by a Japanese agronomist named Toyosigue Morita in order to generate a variety with higher content of Rebaudioside $\mathrm{A}$ and can be spread by seeds (MORITA \& BU, 2000).

Extracts made from Stevia rebaudiana have many applications as sweeteners in the food industry, incorporated into a variety of products; however, eliminate sugar in the formulation of ice cream is not as simple as it may result in a product without adequate sensory characteristics (e.g. scoopability, mouthfeel, or even sweetness) (MARSHALL et al., 2003). Reducing sugar typically causes changes in the colligative properties of the ice cream (e.g. fraction of frozen water, and glass transition temperature) and the rheological properties due to the change in the size and shape of the crystals (SOUKOULIS et al., 2014; CAILLET et al., 2003). Therefore the aim of this research was to evaluate the effect of replacing sugar with different levels of extracts of $\boldsymbol{S}$. rebaudiana Morita II and Criolla, on the physicochemical and sensory properties of strawberry ice cream.

\section{MATERIALS AND METHODS}

\section{Reagents and samples}

Commercial products such as whole milk $\left(\right.$ Lala $\left.^{\circledR}\right)$, heavy cream (Alpura $\left.{ }^{\circledR}\right)$ and frozen strawberries were purchased in a local market. The leaves of two varieties of $\boldsymbol{S}$. rebaudiana, Morita and Criolla II were collected, dried, powdered and kept in the dark until use.

\section{Stevia rebaudiana extracts}

The leaves of two varieties of $\boldsymbol{S}$. rebaudiana, Morita and Criolla II, were grown in the Southeast of Mexico. For preparing extracts, $0.5 \mathrm{~g}$ of powdered leaves were weighed and extracted three times with water with $5 \mathrm{~mL}$ each time in a boiling water bath at $100^{\circ} \mathrm{C}$ for $30 \mathrm{~min}$. Extracts were cooled to room temperature and centrifuged for 10 minutes $\left(2,500 \times \mathrm{g}, 10^{\circ} \mathrm{C}\right)$ to facilitate separation of the aqueous phases of the leaves. The aqueous phases were transferred to a $25 \mathrm{~mL}$ volumetric flask and filled to capacity after the last extraction (WÖELWERRIECK et al., 2010).

Ice cream formulations

A $2 \times 2$ factorial experimental design was used to prepare the ice cream formulations. Factors and levels were: variety of Stevia (Criolla or Morita II) and concentration of extract used ( 5 or $8 \%$ ) based on the original formulation. Four formulations (Table 1) were formed by combining different levels of each of the variables, performing two replicates

Table 1 - Strawberry ice cream formulations with Stevia rebaudiana.

\begin{tabular}{|c|c|c|c|c|c|}
\hline \multirow{2}{*}{ Ingredients } & Control & $\mathrm{F} 1$ & $\mathrm{~F} 2$ & $\mathrm{~F} 3$ & F4 \\
\hline & \multicolumn{5}{|c|}{--------------Amount (\% w/v)------------ } \\
\hline Whole milk & 28.02 & 30.24 & 29.24 & 30.24 & 29.24 \\
\hline Strawberry & 32.45 & 35.16 & 34.16 & 35.16 & 34.16 \\
\hline Heavy cream & 27.02 & 29.3 & 28.3 & 29.3 & 28.3 \\
\hline $\mathrm{CMC}$ & 0.3 & 0.3 & 0.3 & 0.3 & 0.3 \\
\hline Sugar & 12.21 & --- & --- & --- & --- \\
\hline Stevia rebaudiana & --- & 5 & 8 & 5 & 8 \\
\hline
\end{tabular}

Formulations prepared (F1: Morita II 5\%, F2: Morita II 8\%, F3: Criolla 5\%, F4: Criolla 8\%).

Values are based on $100 \mathrm{ml}$ of ice cream mix. 
of each formulation. Additionally a control group was prepared using sugar as sweetener. The base formulation was determined through preliminary tests developed in the laboratory.

Accordingly to formulation (Table 1), ingredients were weighed in the balance and placed in a blender to homogenize the mixture; they were liquefied until lumps disappear completely and then the mixture was subjected to whipping process in ice cream machine Taylor (previously frozen), where it underwent 5-7 minutes of mixing cold and $2 \mathrm{~min}$ of aeration. At the end of this time, the mixture was stored at $-18^{\circ} \mathrm{C}$ until analysis.

\section{Proximate analysis}

The proximate analysis of the four formulations was performed based on the methodologies proposed by the Association of Official Analytical Chemists (AOAC, 1997). Briefly: moisture (method 925.09) was determined by drying the sample in a convection oven at $110^{\circ} \mathrm{C}$ for 2 hours; ashes (method 923.03) were quantified by burning the sample at $550^{\circ} \mathrm{C}$ in a muffle; crude protein content (method 954.01) was estimated in a digester by Kjendahl method ( $\mathrm{N} \times$ 6.38); crude fiber (method 962.09) was determined with a sequential acid and base digestion; fat was extracted by Soxhlet method for 80 minutes using hexane as the extraction solvent and Soxtec Foss apparatus at $120^{\circ} \mathrm{C}$ (method 920.39); and finally, carbohydrate content was established by difference and expressed as nitrogen-free extract.

Physicochemical analysis

To assess the quality of the ice cream, the following physicochemical parameters were determined:

Overrun (Constant Volume Method): Five hundred milliliters of the mixture were subjected to 5 minutes of mixing and then subjected to airy for two minutes in a Taylor machine (104-27 Illinois, USA); then the volume was measured and the overrun (\%) was calculated, according to the equation volume of [(ice cream - volume of mix) / volume of mix x 100] (DERVISOGLU et al., 2005).

Mass of ice melted (Method Cottrell): The ice cream samples were weighed $(20 \mathrm{~g})$ and placed on a wire mesh $\left(1.15 \mathrm{~mm}^{2}\right)$; a previously weighed beaker was placed $10 \mathrm{~cm}$ beneath the mesh to collect the melted ice cream. The system was kept at room temperature for $30 \mathrm{~min}$ and then, the beaker with the melted ice cream was weighed and the mass of ice melted was calculated (COTTRELL et al., 1979). The assay was performed in duplicate for all samples.

Viscosity: The viscosity was determined as a percentage of torque and viscosity ( $\mathrm{Pa} \mathrm{x} \mathrm{s}$ ) in $8.6 \mathrm{~mL}$ of the ice cream mixture at $4^{\circ} \mathrm{C}$. Brookfield DV-II+ Pro viscometer was used programmed in a shear rate range of $100-200(1 / \mathrm{s})$.

\section{Sensory analysis}

Among the four formulations of strawberry ice cream sweetened with Stevia rebaudiana, those products containing a higher concentration of aqueous extract of Stevia rebaudiana to provide a sufficient level of sweetness were selected by the formulator team to be tested. Since, $\boldsymbol{S}$. rebaudiana Criolla contains more of stevioside and less rebaudioside A (ARANDA-GONZÁLEZ et al., 2014), the formulation F3 was discarded for sensory evaluation, as it was the less sweet product; therefore only F1, F2 and F4 were evaluated by a group of non-expert judges composed of 80 panelists.

The judges were of either sex, ranging in age between 20 and 50 years old, consisting of students, faculty and quartermaster staff of the Faculty of Chemical Engineering at the Universidad Autónoma de Yucatán. The judges noted the level of pleasure or displeasure through an unstructured hedonic scale of $10 \mathrm{~cm}$ (Figure 1). The response variable was the level of satisfaction of products expressed in centimeters and was analyzed based on a statistical design with a completely random distribution.

\section{Statistical analysis}

The statistical analysis of proximate and physicochemical composition was performed by analysis of one-way variance; sensory analysis was subjected to non-parametric Kruskal-Wallis test. Differences were considered significant at $\mathrm{P}<0.05$ using Statgraphics plus software.

\section{RESULTS AND DISCUSSION}

The proximate composition of the different formulations of ice cream is given in table 2. As seen in table 2 , those ice cream made with the same variety

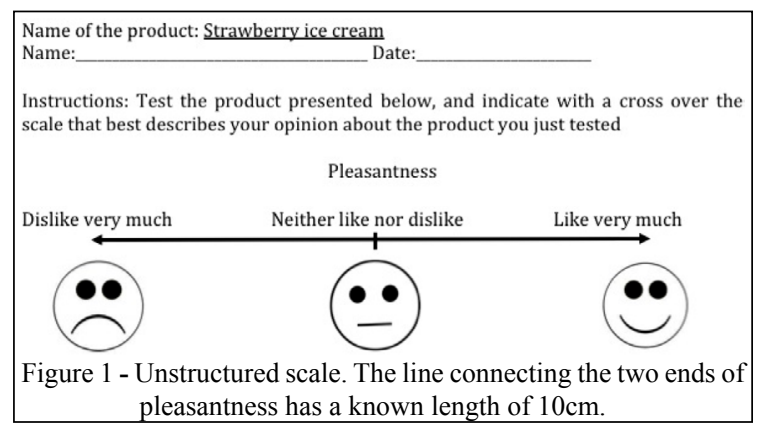

Ciência Rural, v.46, n.4, abr, 2016. 
Table 2 - Proximate composition of different formulation of ice cream sweetened with $\boldsymbol{S}$. rebaudiana extracts (\% dry basis).

\begin{tabular}{lllll}
\hline Parameter (\%) & F1 & F2 & F3 & F4 \\
\hline Moisture & $4.00^{\mathrm{a}}$ & $4.20^{\mathrm{a}}$ & $2.09^{\mathrm{b}}$ & $2.23^{\mathrm{b}}$ \\
Ash & $1.23^{\mathrm{a}}$ & $1.26^{\mathrm{a}}$ & $0.70^{\mathrm{b}}$ & $0.71^{\mathrm{b}}$ \\
Crude fiber & $1.02^{\mathrm{b}, \mathrm{c}}$ & $1.32^{\mathrm{a}}$ & $0.94^{\mathrm{c}}$ & $1.06^{\mathrm{b}}$ \\
Fat & $23.02^{\mathrm{a}, \mathrm{b}}$ & $22.41^{\mathrm{b}}$ & $23.82^{\mathrm{a}}$ & $22.63^{\mathrm{b}}$ \\
Protein & $5.51^{\mathrm{a}}$ & $5.69^{\mathrm{a}}$ & $2.48^{\mathrm{c}}$ & $2.86^{\mathrm{b}}$ \\
Carbohydrate & $65.22^{\mathrm{c}}$ & $65.12^{\mathrm{c}}$ & $69.97^{\mathrm{b}}$ & $70.51^{\mathrm{a}}$ \\
\hline
\end{tabular}

Formulations prepared (F1: Morita II 5\%, F2: Morita II 8\%, F3: Criolla 5\%, F4: Criolla 8\%).

${ }^{\mathrm{a}-\mathrm{c}}$ Different letters in rows indicate significant differences at $\mathrm{P}<0.05$.

of Stevia rebaudiana have a proximate analysis similarly to each other, but slightly different to the other variety. In other words, F1 and F2, which were made with $\boldsymbol{S}$. rebaudiana Morita II, are similar but somewhat different from F3 and F4 that were made with $S$. rebaudiana Criolla. Comparison between formulations having the same amounts of ingredients (F1 and F2 to F3 with F4) was obtained statistical difference $(\mathrm{P}<0.05)$ in moisture content, ash, fiber and carbohydrates respect to the variety of extract used. In the case of fat, no significant difference $(\mathrm{P}>0.05)$ was reported. Generally, the component contents were higher when the extract of Stevia rebaudiana Morita variety was used.

In both varieties, the level of addition had an effect on proximal composition of ice cream; in Morita variety, level of addition increased the crude fiber with significant differences between formulations 1 and $2(\mathrm{P}<0.05)$; in the Criolla variety, the formulation with more Stevia extract (F4) had higher content of crude fiber, protein and carbohydrates, while lower crude fat which was statistically different compared with F3 $(\mathrm{P}<0.05)$. This is probably due to the differences between the chemical constituents present in the leaves of the varieties, as has been reported by SEGURA-CAMPOS et al. (2014).

The low humidity occasioned by the fruit solids used (by the use of frozen strawberries instead of syrup or marmalade), caused $t$ a gritty texture (F3 and F4). It has been reported that solids in ice cream have an important role, as its lack made the structure weak but if they are in excess, the product will present a gritty texture (LÓPEZ-BARÓN et al., 2010). The ash content in F1 and F2, were similar and so did F3 and F4, accordingly to Stevia variety used. Varieties of $\boldsymbol{S}$. rebaudiana cultivated in Mexico contain high amounts of ashes ranging from 7.82$11.93 \%$ dry basis (SEGURA-CAMPOS et al., 2014). However, according to RAHMESH et al. (2006), growth conditions may affect the final content.

Regarding the fiber in the four formulations, the Stevia rebaudiana may provide it given that it is a good source of fiber (5.92-9.52\% dry basis) according to SEGURA-CAMPOS et al. (2014) or simply from the fruit used in the formulation. As for the crude fat, the four treatments showed a great content, as the fat content in a standard ice cream formulation is about 12\% (ARBUCKLE \& MARSHALL, 2000). Given that any variety of Stevia contains fat, it is almost certain that is given by the milk and cream used in the formulation. Future formulations could consider using some fat replacers ingredients (e.g. inulin) (BARRIONUEVO et al., 2011), which would improve this aspect.

Apparent viscosity value of treatments to a strain rate of $101 / \mathrm{s}$ varied in a range of $0.062-0.324 \mathrm{~Pa}$ $\mathrm{x} \mathrm{s}$ at $23^{\circ} \mathrm{C}$ (Figure 2), however all four formulation had significantly lower viscosity compared to control $(3.563 \mathrm{~Pa} \times \mathrm{s})$. This was due to the thickener and plasticizer effects of sucrose in solution at high concentrations. As shown in figure 2, the viscosities of all ice cream mixes studies were decreasing as the shear rate was increased, indicating a pseudoplastic or shear-thinning behavior. Also, the percentage of the extract increased viscosity statistically significant $(\mathrm{P}<0.05)$; Viscosity of ice cream mix is affected by several factors, such as composition, kind and quality of ingredients, processing and handling of mix, total solids, and temperature (PATEL et al., 2011). Among the formulations made with $\boldsymbol{S}$. rebaudiana, Morita II 8\% (F2) showed the higher

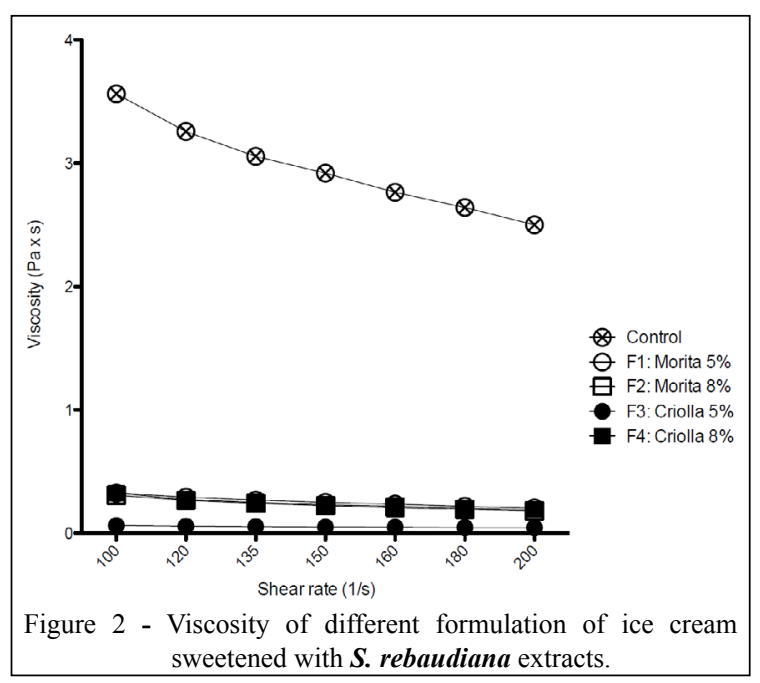

Ciência Rural, v.46, n.4, abr, 2016. 
viscosity that could be caused by the amount of water (Table 2) and their ability to establish hydrogen bonds (PATEL et al., 2011).

Table 3 presents the results ofmeasurements of melted ice cream and whipping performance with different substitution levels and varieties of Stevia rebaudiana extract used.

In the overrun test, it has been reported that when the apparent viscosity increases, the melt strength and softness of the body increases, but decreases performance whipping (ARBUCKLE \& MARSHALL, 2000) which was observed in this study for ice cream obtained with sucrose respect to ice cream prepared with stevia extract. The ANOVA indicated that the stevia variety and extract concentration had significant influence $(\mathrm{P}<0.05)$ on overrun, it was observed that the higher the concentration of extract, the lower the percentage of yield of whipping in both varieties.

In the test of melted mass, it was observed that in the control ice cream, the formulation with higher viscosity had lower melted mass (Table 2). The ANOVA data show that significant effect $(\mathrm{P}<0.05)$ of stevia variety on melted mass. The ice cream sweetened with stevia Criolla extract showed less tendency to melt. The low or rapid melting is generally related to the amount of sweetener, stabilizer and/or emulsifier, therefore modifying this ingredient can modify such condition.

Among the four formulations, F1, F2 and F4 were subjected to sensory analysis; development group discarded formulation 3 , due to its low sweetness. The average score awarded by the panelist are presented in figure 3 with significant differences $(\mathrm{P}<0.05)$. More importantly, the ratings of the three evaluated formulations were above 5, which was above the point of indifference.

Table 3 - Physicochemical parameters of different formulation of ice cream sweetened with $S$. rebaudiana extracts.

\begin{tabular}{lcc}
\hline Product & Overrun $(\%)$ & Melted mass $(\mathrm{g})$ \\
\hline Control & $52.3^{\mathrm{d}}$ & $9.30^{\mathrm{a}}$ \\
F1 & $64.0^{\mathrm{a}, \mathrm{b}}$ & $4.01^{\mathrm{b}}$ \\
F2 & $61.1^{\mathrm{c}}$ & $4.00^{\mathrm{b}}$ \\
F3 & $65.2^{\mathrm{a}}$ & $3.24^{\mathrm{c}}$ \\
F4 & $63.4^{\mathrm{b}}$ & $2.98^{\mathrm{c}}$ \\
\hline
\end{tabular}

Formulations prepared (F1: Morita II 5\%, F2: Morita II 8\%, F3: Criolla 5\%, F4: Criolla 8\%).

${ }^{\mathrm{a}-\mathrm{d}}$ Different letters in columns indicate significant differences at $\mathrm{P}<0.05$.

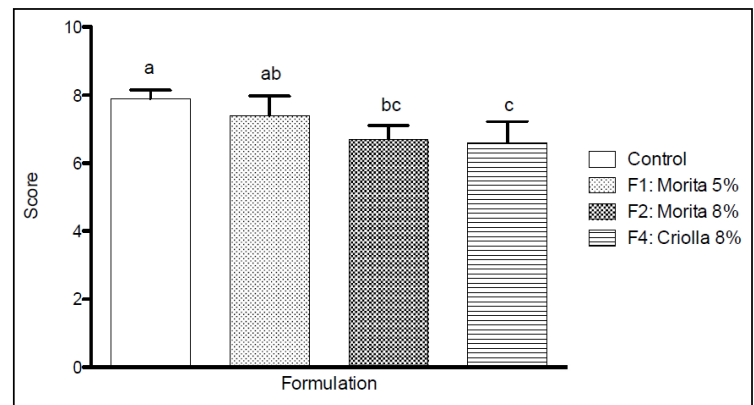

Figure 3 - Effect of $\boldsymbol{S}$. rebaudiana addition on the sensory properties of strawberry flavored ice cream. The values represent the average score by the judges. Similar letters represent no significant differences

\section{CONCLUSION}

Four different formulations of ice cream sweetened with Stevia rebaudiana Morita II and Criolla were developed, whose proximate composition and physicochemical parameters were evaluated. Sensory evaluation showed significant differences between the products obtained, however all of them with a score above the indifference point suggesting that those products would have a potential to be commercialized.

\section{ACKNOWLEDGEMENTS}

This work was supported by Programa de Mejoramiento al Profesorado (PROMEP-SEP) and CONACYT's scholarship.

\section{BIOETHICS AND BIOSSECURITY COMMITTE APPROVAL}

The authors of the article entitled " Replacing sugar with $\boldsymbol{S}$. rebaudiana extracts on the physicochemical and sensory properties of strawberry ice cream" declared, for all due purposes, that the project that gave rise to the present data has not been submitted for evaluation to the Ethics Committee of the "Universidad Autónoma de Yucatán (Cuerpo Académico de Desarrollo Alimentario", but we are aware of the contents of Resolution No. 466, of December 12, 2012 of the Brazilian National Health Council http://conselho.saude. gov.br/resolucoes/2012/Reso466.pdf' if it involves human.

Thus, the authors assume full responsibility for the presented data and are available for possible questions that should be required by the competent authorities.

\section{REFERENCES}

ACADEMY OF NUTRITION AND DIETETICS. Position of the Academy of Nutrition and Dietetics: use of nutritive and nonnutritive sweeteners. J Acad Nutr Diet, v.112, p.739-758, 2012. Available from: <http://dx.doi.org/10.1016/j.jand.2012.03.009>. Accessed: Mar. 7, 2015. doi: 10.1016/j.jand.2012.03.009.

Ciência Rural, v.46, n.4, abr, 2016. 
AOAC (ASSOCIATION OF OFFICIAL ANALYTICAL CHEMISTS). Official methods of analysis. Washington, D.C.: Editorial William Horwitz, 1997. V.15

ARANDA-GONZÁLEZ, I.I. et al. Evaluación de la inocuidad de Stevia rebaudiana Bertoni cultivada en el sureste de México como edulcorante de alimentos. Nutr Hosp, v.30, n.3, p.594-601, 2014. Available from: <http://www.aulamedica.es/nh/pdf/7634.pdf $>$. Accessed: Aug. 2015. doi: 10.3305/nh.2014.30.3.7634.

ARBUCKLE, W.S.; MARSHALL R.T. Ice cream. 5.ed. Local: editora Springer, 2000. p. 364.

BARRIONUEVO, M. et al. Formulación de un helado dietético sabor arándano con características prebióticas. DIIAETA (B. Aires), v.29, n.134, p.23-28, 2011. Available from: <http://www. scielo.org.ar/pdf/diaeta/v29n134/v29n134a04.pdf>. Accessed: Mar. 17, 2015.

CAILLET, A. et al. Characterization of ice cream structure by direct optical microscopy. Influence of freezing parameters. LebensmWiss u-Technol, v.36, p.743-749, 2003. Available from: <http:// dx.doi.org/10.1016/S0023-6438(03)00094-X>. Accessed: Mar. 25, 2015. doi: 10.1016/j.foodqual.2004.05.009.

COTTRELL, J.I.L. et al. Assessment of polysaccharides as ice cream stabilizers. J Sci Food Agr, v.30, p.1085-1086, 1979.

DERVISOGLU, M. et al. The effect of soy protein concentrate addition on the physical, chemical and sensory properties of strawberry flavored ice cream. Eur Food Res Technol, v.221, p.466-470, 2005. Available from: <http://link.springer.com/ article/10.1007\%2Fs00217-005-1207-3\#page-1>. Accessed: Aug. 12, 2015. doi: 10.1007/s00217-005-1207-3

FDA (FOOD AND DRUG ADMINISTRATION). Code of Federal Regulations Title 21, V.2, Part 135. Frozen desserts, subpart B. Requirements for Specific Standardized Frozen Desserts, Sec. 135.110. Ice cream and frozen custard. Available from: <http:// www.accessdata.fda.gov/scripts/cdrh/cfdocs/cfcfr/cfrsearch. cfm?fr=135.110>. Accessed: Aug. 18, 2015.

KLURFELD, D.M. What do government agencies consider in the debate over added sugars? Adv Nutr, v.4, p.257-261, 2013. Available from: <http://dx.doi.org/10.3945/an.112.003004>. Accessed: Mar. 9, 2015. doi: 10.3945/an.112.003004.

LEMUS-MONDACA, R. et al. Stevia rebaudiana Bertoni, source of a high-potency natural sweetener: a comprehensive review on the biochemical, nutritional and functional aspects. Food Chem, v.132, p.1121-1132, 2012. Available from: <http://
www.sciencedirect.com/science/article/pii/S0308814611017559>. Accessed: May 20, 2015.

LÓPEZ-BARÓN, F.N. et al. Ensayo y Funcionalidad de un Sustituyente de Sólidos No Grasos Lácteos en una Mezcla para Helado. Rev Fac Nal Agr Medellín, v.63, n.2, p.5729-5744, 2010. Available from: <http://www.scielo.org.co/pdf/rfnam/v63n2/ a25v63n01.pdf>. Accessed: Mar. 22, 2015.

MARSHALL, R.T. DOUGLAS, G.H., HARTEL, R.H. Ice cream. 3.ed. New York: Aspen Publishers, 2003. p 357.

MORITA, T.; BU, Y. Variety of Stevia rebaudiana Bertoni. U.S. Patent 6,031,157, 2000 .

PATEL, M. et al. Evaluation of Suitability of Sago (Tapioca Starch) As a Functional Ingredient in Ice Cream. Indian J Fund and Appl. Life Sci, v.1, n.2, p.111-118, 2011. Available from: $<$ http://www. cibtech.org/IJFALS_Vol.1.Issue2.htm>. Accessed: Mar. 25, 2015.

RAHMESH, K. et al. Cultivation of Stevia (Stevia rebaudiana (Bert) Bertoni): a comprehen- sive review. Adv Agron, v.89, n.1, p.137-177, 2006. Available from: <http:/www.sciencedirect.com/ science/article/pii/S0065211305890030>. Accessed: Mar. 18, 2015. doi: 10.1016/S0065-2113(05)89003-0.

RAMÍREZ-JARAMILLO, G. et al. Estevia (Stevia rebaudiana, Bertoni), un cultivo con potencial productivo en México. Mérida, Yucatán, México: Instituto Nacional de Investigaciones Forestales, Agrícolas y Pecuarias. Centro de Investigación Regional Sureste, 2011. P. 79.

SEGURA-CAMPOS, M. et al. Comparison of chemical and functional properties of Stevia rebaudiana (Bertoni) varieties cultivated in Mexican Southeast. Am J Plant Sci, v.5, p.286293, 2014. Available from: <http://dx.doi.org/10.4236/ ajps.2014.53039>. Accessed: Mar. 30, 2015. doi: 10.4236/ ajps.2014.53039.

SOUKOULIS, C. et al. Ice cream as a vehicle for incorporating health-promoting ingredients: conceptualization and overview of quality and storage stability. Compr Rev Food Sci and Food Saf, v.13, p.627-655, 2014. Available from: <http://dx.doi. org/10.1111/1541-4337.12083>. Accessed: Mar. 27, 2015. doi: $10.1111 / 1541-4337.12083$

WÖELWER-RIECK, U. et al. Improved HPLC method for evaluation of the major steviol glycosides in leaves of Stevia rebaudiana. Eur Food Res Technol, v.231, p.581-588, 2010. Available from: <http://dx.doi.org/10.1007/s00217-010-1309-4>. Accessed: Mar. 21, 2015. doi: 10.1007/s00217-010-1309-4. 